Article

\title{
Sustainability Benefits Assessment of Metakaolin-Based Geopolymer Treatment of High Plasticity Clay
}

\author{
Rinu Samuel ${ }^{1}$, Anand J. Puppala ${ }^{2, *}$ and Miladin Radovic ${ }^{3}$ \\ 1 Department of Civil Engineering, University of Texas at Arlington, Arlington, TX 76019, USA; \\ rinu.samuel@mavs.uta.edu \\ 2 Zachry Department of Civil and Environmental Engineering, Texas A\&M University, College Station, \\ TX 77843, USA \\ 3 Department of Materials Science and Engineering, Texas A\&M University, College Station, TX 77843, USA; \\ mradovic@tamu.edu \\ * Correspondence: anandp@tamu.edu
}

Received: 10 November 2020; Accepted: 10 December 2020; Published: 15 December 2020

\begin{abstract}
Expansive soils are prevalent world over and cause significant hazards and monetary losses due to infrastructure damages caused by their swelling and shrinking behavior. Expansive soils have been conventionally treated using chemical additives such as lime and cement, which are known to significantly improve their strength and volume-change properties. The production of lime and cement is one of the highest contributors of greenhouse gas emissions worldwide, because of their energy-intensive manufacturing processes. Hence, there is a pressing need for sustainable alternative chemical binders. Geopolymers are a relatively new class of aluminosilicate polymers that can be synthesized from industrial by-products at ambient temperatures. Geopolymer-treated soils are known to have comparable strength and stiffness characteristics of lime and cement-treated soils. This study evaluates the sustainability benefits of a metakaolin-based geopolymer treatment for an expansive soil and compares its results with lime treatment. Test results have shown that geopolymers have significantly improved strength, stiffness, and volume-change properties of expansive soils. Increased dosages and curing periods have resulted in further property enhancements. Swell and shrinkage studies also indicated reductions in these strains when compared to control conditions. The sustainability benefits of both geopolymer and lime treatment methods are evaluated using a framework that incorporates resource consumption, environmental, and socio-economic concerns. This study demonstrates geopolymer treatment of expansive soils as a more sustainable alternative for expansive soil treatments, primarily due to metakaolin source material. Overall results indicated that geopolymers can be viable additives or co-additives for chemical stabilization of problematic expansive soils.
\end{abstract}

Keywords: geopolymer; soil stabilization; expansive soils; sustainability benefits; sustainable ground improvement

\section{Introduction}

Soils that exhibit volume-change upon variation of their moisture content are known as expansive soils. The swelling and shrinking nature of expansive soils is mostly attributed to the proportion of the clay mineral smectite in the soil, as well as the interaction of water with the clay mineral surfaces [1]. The extent of swelling and shrinkage of expansive soils are also dependent on other factors such as soil suction, soil dry unit weight, stress-history, climate, and active zone depth [2]. Expansive soils can prove to be especially hazardous in places with cycles of dry and wet spells resulting in repeated cycles 
of swelling and shrinkage. The effects of expansive soils are mostly observed near the ground surface where desiccation cracks can be seen in the dry season; further damages caused include pavement distress or failure, differential uplift or settlement of structures, slope and foundation failures, and other damages that compromise the integrity of infrastructures. Expansive soils are present all over the world and are ubiquitous in the south-western United States [3-6]. Millions of dollars are spent each year in the United States alone to fix damages caused to infrastructures by expansive soils [3,7-10]. As such it is important to improve swelling and shrinkage characteristics of expansive soils before proceeding with infrastructure development.

Stabilization of expansive soils has been conventionally performed using chemical additives such as lime and cement, which have proven to significantly improve the strength and lower the volume-change behavior of expansive soils by a series of cationic exchange and pozzolanic reactions between the additive and soil particles [11-13]. These calcium-based conventional chemical additives are known to have durability issues, in addition to having disadvantages in sulfate-rich soils, as certain chemical reactions result in the formation of the mineral ettringite, which causes excessive swelling and volume-change in soils $[14,15]$. The high demand of lime and cement additives has led to their mass production, which in turn reduces their unit cost, ultimately driving the low-cost production cycle. The cost benefits that lime and cement offer are progressively being overshadowed by their environmental implications. The production of lime and cement are energy-intensive operations that require kilns to be heated between $1000{ }^{\circ} \mathrm{C}$ to $1500{ }^{\circ} \mathrm{C}$ to process raw materials. A 2018 inventory of the greenhouse gas emissions by the Environmental Protection Agency (EPA) reported that lime and cement production industries produced 97 million metric tons of carbon dioxide $\left(\mathrm{CO}_{2}\right)$ from the minerals sector alone [16]. As such, there is an imminent need to focus on sustainable alternatives or co-additives for lime and cement treatment works in pavement geotechnics.

The topic of sustainability is usually met with a lot of apprehension, as it is relatively new and can have a myriad of different interpretations. Nevertheless, Brundtland's Declaration provides a widely recognized commentary which states that "sustainable development is development that meets the needs of the present without compromising the ability of future generations to meet their own needs" $[17,18]$. The prospect of integrating sustainability into a project is highest during the planning phase and diminishes considerably as the project moves into implementation phases [19]. Since geotechnics is applied in the early stages of a project, it renders an advantage and responsibility to implement sustainable geotechnical practices that positively influence the subsequent phases of infrastructure development. The engineering perspective of sustainability often incorporates cost-efficiency and reasonable control of harmful emissions, in addition to prudent resource consumption $[20,21]$. Therefore, a comprehensive sustainability approach includes environmental protection, economic development, and social development [18]. Regrettably, environmental impacts have been sidelined for far too long for the sake of monetary benefits, and therefore need to be addressed with more weightage for constructive sustainability with lasting positive impacts.

In recent years, a new class of binder materials known as geopolymers have been hailed as a more sustainable and eco-friendly alternative to lime and cement, due to comparable compressive strength, durability, and low shrinkage properties [22-24]. Geopolymers are aluminosilicate polymers that can be synthesized from industrial by-products, such as metakaolin, fly ash, and clay [25-28], relatively quickly at ambient temperatures thereby having a significantly lower carbon footprint than lime or cement binders [29,30]. Geopolymers consist of extensive three-dimensional structures of covalently bonded aluminosilicates formed by the alkali activation of aluminosilicate rich materials [24]. They are essentially rigid gels that may evolve to form amorphous or crystalline materials under certain temperature and pressure conditions [31]. Chemically, geopolymers can be classified as polysialates and can be represented by their empirical formula as shown in Equation (1) [25].

$$
\mathrm{M}_{\mathrm{n}}\left[-\left(\mathrm{SiO}_{2}\right)_{\mathrm{z}}-\mathrm{AlO}_{2}\right]_{\mathrm{n}} \cdot \mathrm{wH}_{2} \mathrm{O}
$$


where, $\mathrm{M}$ is the alkali metal cation (such as $\mathrm{Na}, \mathrm{K}$, or $\mathrm{Ca}$ ), $\mathrm{n}$ is the degree of polycondensation, $\mathrm{z}$ is the silicon to aluminum (Si:Al) ratio (usually 1, 2, or 3), and $\mathrm{w}$ is the molar water amount. Geopolymers are formed in a high $\mathrm{pH}$ environment through an alkali-activated polycondensation reaction comprising of five stages-dissolution, speciation equilibrium, gelation, reorganization, and polymerization and hardening $[10,24,32]$. The synthesis of geopolymers requires an aluminosilicate-rich source (metakaolin, fly ash), an alkali-metal cation source (such as $\mathrm{NaOH}, \mathrm{KOH}$, or $\mathrm{Ca}(\mathrm{OH})_{2}$ ), an additional source of silica (as needed), and water. Predetermined ratios of the components are mixed to form a slurry which on curing form a hardened geopolymer. The transformation of the slurry to form the hardened geopolymer is the result of overlapping polycondensation reactions of the dissolved aluminosilicate species in an aqueous solution resulting in their subsequent polymerization, gelation, and hardening [33]. The gelation of different aluminosilicate species and characteristics of their respective geopolymer formations are dependent on various factors such as concentration of reactive species in solution, raw material type and quality, water content, curing conditions, and time [29,34,35]. Recent studies have shown that metakaolin-based geopolymers significantly improved the strength and volume-change properties of expansive soils [10,33,36,37].

The focus of this study is to assess the sustainability benefits of the metakaolin-based geopolymer used by the authors to successfully treat a high plasticity expansive clayey soil $[10,33]$. The sustainability benefits of the metakaolin-based geopolymer in this study were evaluated based on the sustainability framework developed at University of Texas at Arlington, which utilizes a weighted multi-criterial evaluation based on resource consumption, environmental impact, and socio-economic impact [18]. Additionally, sustainability benefits were assessed for the conventional lime treatment of the same clay.

\section{Materials and Methods}

\subsection{Materials}

A potentially expansive subgrade soil was obtained from Lewisville, Denton county in North Texas for soil treatment work. The soil was subjected to a series of basic geotechnical characterization tests as per the ASTM International (ASTM) standards to better understand its properties, which are summarized in Table 1. The soil was tested for particle size distribution (ASTM D6913-17, D7928-17) and Atterberg limits (ASTM D4318-17, TEX 105-E) and based on these results, the soil was classified as per the Unified Soil Classification System (USCS) method as a high-plasticity clay (CH) with a plasticity index (PI) of 53\%, indicating a high swelling potential. Moisture content-dry density relationships (ASTM 44609-94, GR-84-14) were determined to obtain the optimum moisture content (OMC) at which the soil was compacted to its maximum dry density (MDD). The soil was oven-dried, crushed, and subsequently pulverized before being subjected to engineering tests and chemical treatments.

Table 1. Basic geotechnical properties of Lewisville soil.

\begin{tabular}{|c|c|c|c|c|c|c|c|c|}
\hline & $\begin{array}{c}\text { Sand Content } \\
(\%)\end{array}$ & $\begin{array}{c}\text { Silt Content } \\
(\%)\end{array}$ & $\begin{array}{c}\text { Clay Content } \\
(\%)\end{array}$ & $\begin{array}{l}\text { LL }^{1} \\
(\%)\end{array}$ & $\begin{array}{l}\text { PI }^{2} \\
(\%)\end{array}$ & $\begin{array}{l}\operatorname{MDD}^{3} \\
\left(\mathrm{kN} / \mathrm{m}^{3}\right)\end{array}$ & $\begin{array}{c}\mathrm{OMC}^{4} \\
(\%)\end{array}$ & USCS Classification \\
\hline Lewisville Soil & 9.5 & 37.8 & 52.4 & 80 & 53 & 15.70 & 24 & High plasticity clay \\
\hline
\end{tabular}

Metakaolin $\left(2 \mathrm{SiO}_{2} \cdot \mathrm{Al}_{2} \mathrm{O}_{3}\right)$, a highly reactive pozzolanic material was the sole aluminosilicate source of the geopolymer evaluated in this study. Metakaolin is known to have increased compressive strength, reduced permeability, excellent workability, and significantly lower quantities of calcium oxide in comparison to other commonly used aluminosilicate sources like fly ash [38-40], making it an ideal aluminosilicate source for treatment of an expansive soil from a potentially sulfate-rich area in North Texas. Predetermined quantities of metakaolin and an aqueous alkaline activator solution (composed of potassium hydroxide, silica fume, and water) were mixed at room temperature to form a geopolymer slurry with the following mix proportions: $\left(\mathrm{SiO}_{2}: \mathrm{Al}_{2} \mathrm{O}_{3}\right)=4,\left(\mathrm{H}_{2} \mathrm{O}:\left(\mathrm{Al}_{2} \mathrm{O}_{3}+\mathrm{SiO}_{2}\right)\right)=3$, and $\left(\mathrm{K}_{2} \mathrm{O}: \mathrm{Al}_{2} \mathrm{O}_{3}\right)=1$. The workable geopolymer slurry transforms into a hardened geopolymer upon 
curing at room temperature, with a setting time of 8 days. A simplified schematic of the geopolymer synthesis process is shown below in Figure 1. In this study, geopolymer dosage is presented as the percentage weight of metakaolin (MK) in the geopolymer slurry with respect to the dry weight of soil to be treated. Geopolymer treatment of the high plasticity soil was performed by mixing the appropriate dosage of geopolymer slurry with a predetermined amount of dry soil to form test specimens, and cured at room temperature $\left(22{ }^{\circ} \mathrm{C}\right)$ at $100 \%$ relative humidity for different curing periods. Three dosages of $4 \%, 10 \%$, and $15 \%$ metakaolin (MK) were applied to the soil and tested for strength and volume-change properties [33,41].

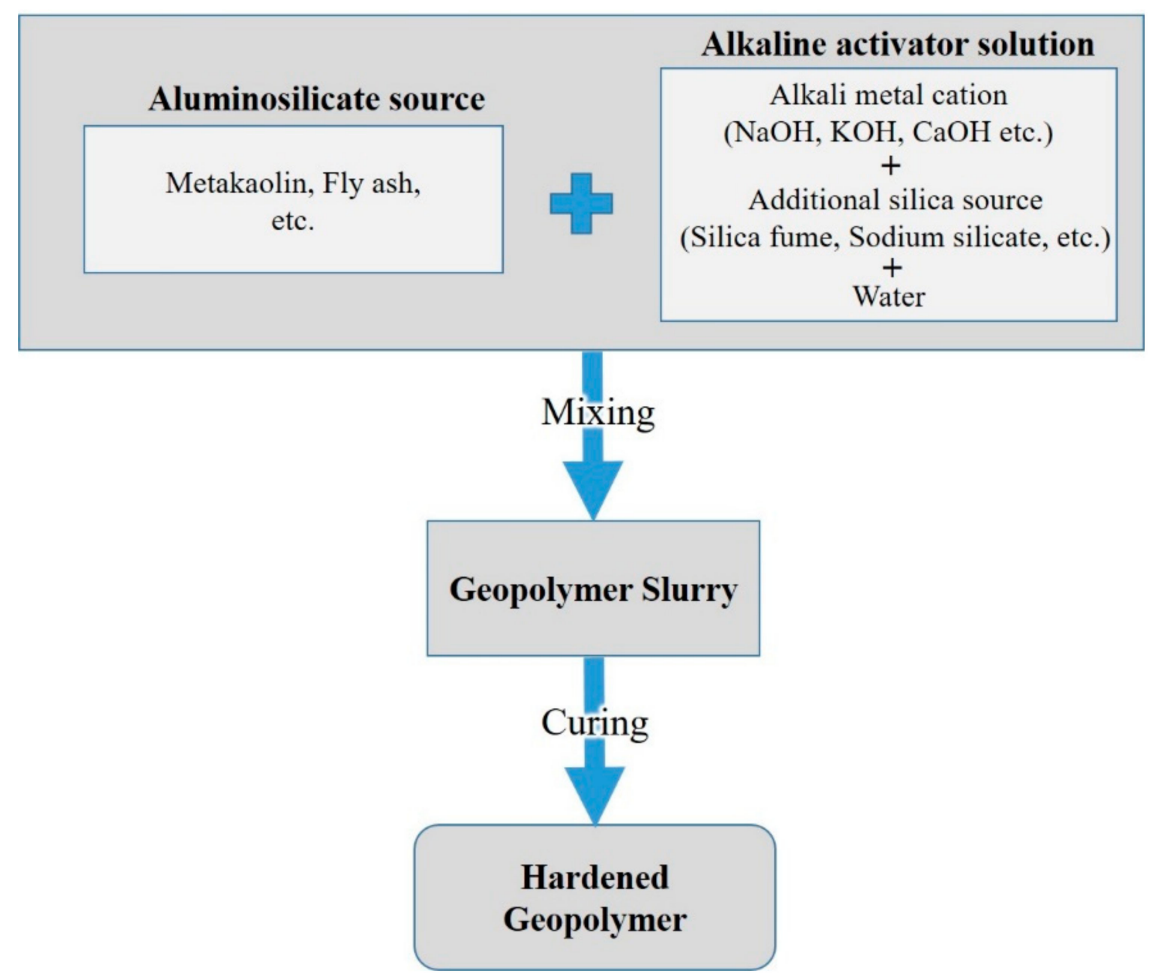

Figure 1. Simplified schematic of geopolymer synthesis [33].

\subsection{Engineering Test Methods}

Efficiency of geopolymer treatment was assessed by performing unconfined compressive strength (UCS), one-dimensional (1-D) swell, and linear shrinkage tests on control (untreated) and geopolymer-treated soil. A set of three tests were performed for each dosage and curing period of every specimen, to ensure reliability of results. The exact procedures of the test methods are described in detail in [33]. All test specimens were molded in three equivalent lifts at their respective OMCs to $95 \%$ of their MDD by static compaction, based on moisture content-dry density relationship tests (ASTM D4609-94) for each soil-geopolymer dosage.

Variations in soil strength before and after geopolymer treatment of $\mathrm{CH}$ were evaluated from UCS tests (ASTM D2166-6). UCS is a critical geotechnical parameter and is known as the highest axial compressive strength an unconfined soil mass can bear before failing. These tests were performed by applying strain-controlled uniaxial loads to right-cylindrical soil specimens until they failed. The stress at which the specimen fails is known as the UCS of the soil, which is also the maximum value of the stress-strain curve obtained from the UCS test. UCS tests were performed on control and geopolymer-treated specimens with diameter of approximately $33.3 \mathrm{~mm}$ (1.31 inches) and height of $72.4 \mathrm{~mm}$ (2.85 inches), with a final height-to-diameter ratio of at least 2. Geopolymer-treated soils were tested for UCS for three different curing periods of 0 (within $2 \mathrm{~h}$ of molding), 7, and 28 days. Figure 2 shows a geopolymer-treated soil specimen before and after UCS testing. 


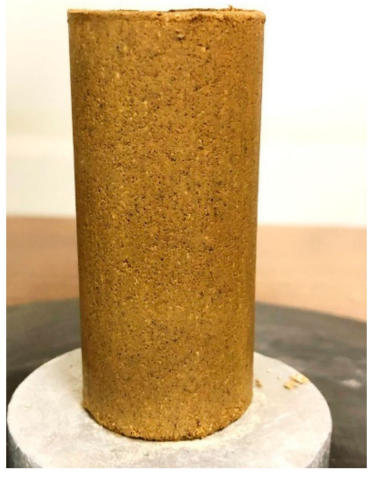

(a)

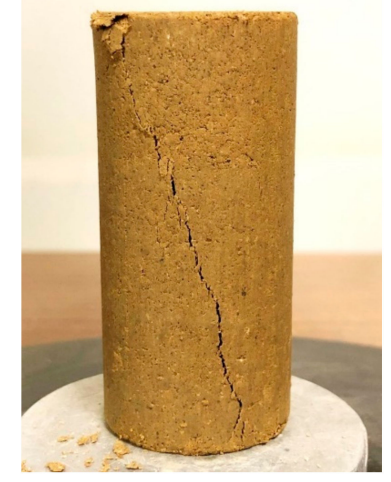

(b)

Figure 2. Unconfined compressive strength (UCS) testing of geopolymer-treated samples: (a) intact soil specimen before testing; (b) failure crack on soil specimen after testing.

The 1-D swell test quantifies the swelling potential of a soil, by determining its free swell. The free swell of a soil is defined as the percentage swell exhibited by the soil following water absorption at a seating pressure of $1 \mathrm{kPa}(0.145 \mathrm{psi})$. 1-D swell tests were performed for control and geopolymer-treated $\mathrm{CH}$ as per ASTM D4546-14e1 using a modified swell test setup, as shown in Figure 3. Compacted soil specimens with approximate diameter of $63.5 \mathrm{~mm}$ ( 2.5 inches) and height of $28.7 \mathrm{~mm}$ (1.13 inches) were placed in ring molds to provide radial confinement. These rings were placed in grooved consolidation cells with a top cap load of $1 \mathrm{kPa}(0.145 \mathrm{psi})$, which were subsequently inundated with water. The vertical strain due to water absorption was monitored by a dial gauge placed on the top cap; swell readings were recorded for a period of at least $24 \mathrm{~h}$ or until no significant strain change was observed. Geopolymer-treated soils were tested for 1-D swell for three different curing periods of 0 (within $2 \mathrm{~h}$ of molding), 3 , and 7 days.

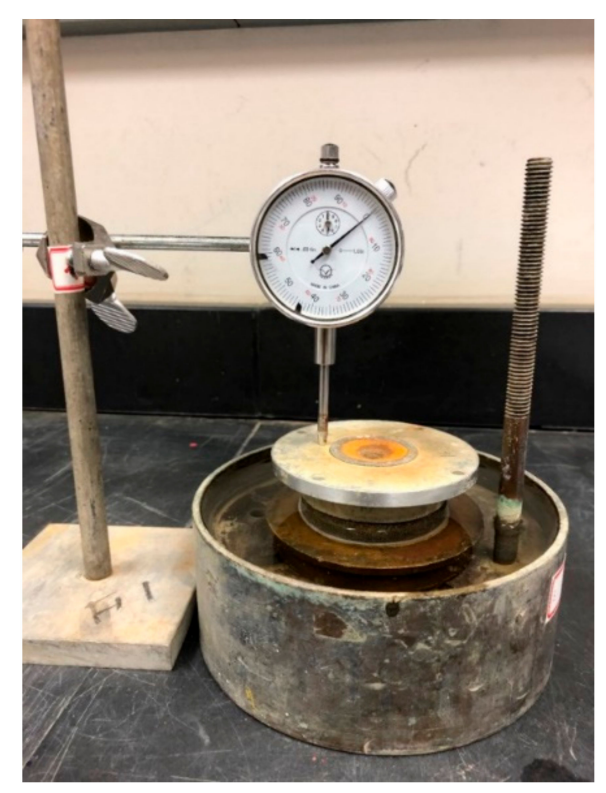

Figure 3. Modified one-dimensional (1-D) swell test setup [33].

The shrinkage potential of control and geopolymer-treated $\mathrm{CH}$ was determined from linear shrinkage tests (TEX-107-E) using soil passing the 425- $\mu \mathrm{m}$ (No. 40) sieve. Water was mixed with soil to form a slurry comparable to its liquid limit consistency, which was subsequently poured into greased linear shrinkage molds of specific length. The slurry molds were smoothed and oven-dried at $110^{\circ} \mathrm{C}$ 
$\left(230^{\circ} \mathrm{F}\right)$ until no further change in mass was observed (Figure 4). On cooling, linear shrinkage was determined by measuring the length of oven-dried soil bars as shown in Equation (2):

$$
\mathrm{LS}=100 \times\left(\mathrm{L}_{\mathrm{W}}-\mathrm{L}_{\mathrm{D}}\right) / \mathrm{L}_{\mathrm{W}}
$$

where LS is the linear shrinkage expressed as a percentage; $\mathrm{L}_{\mathrm{W}}$ is the length of the wet soil bar, $127 \mathrm{~mm}$ (5 inches); and $\mathrm{L}_{\mathrm{D}}$ is the length of the dry soil bar, $\mathrm{mm}$ (inches). Geopolymer-treated soils were tested for linear shrinkage for three different curing periods of 0 (within $2 \mathrm{~h}$ of molding), 3 , and 7 days.

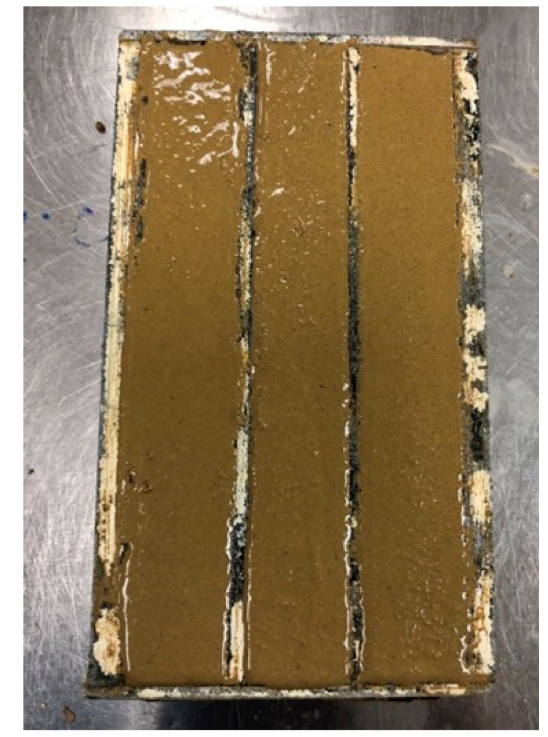

(a)

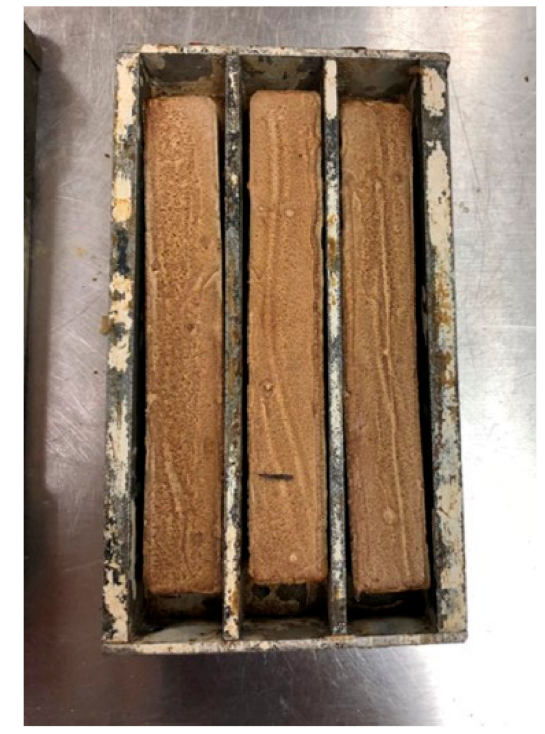

(b)

Figure 4. Linear shrinkage testing of geopolymer-treated samples: (a) soil slurry in shrinkage mold before oven-drying; (b) soil slurry in shrinkage mold after oven-drying.

\subsection{Engineering Test Results}

Significant improvement was observed in compressive strength of geopolymer-treated $\mathrm{CH}$ soil when compared to control $\mathrm{CH}$ material, as shown in Figure 5. The 28-day cured strength of $\mathrm{CH}$ treated with the lowest ( $4 \% \mathrm{MK}$ ) geopolymer dosage was observed to be $100 \%$ higher than control $\mathrm{CH}$ soil with an UCS of 20 psi. The intermediate (10\% MK) and highest (15\% MK) geopolymer dosages exhibited much higher strength increase by about $225 \%$ and $520 \%$, respectively. Immediate strength improvement was observed in treated $\mathrm{CH}$ soil with the lower and intermediate dosages of geopolymer, while the highest dosage required a curing period of 7 days for pronounced strength improvement. From UCS tests, the intermediate dosage of $10 \%$ MK geopolymer was found to be sufficient for significantly increasing the compressive strength of $\mathrm{CH}$ soil.

1-D swell and linear shrinkage tests were conducted to detect changes in volume-change properties of control and geopolymer-treated $\mathrm{CH}$ soil. Control $\mathrm{CH}$ soil exhibited vertical swell strain and linear shrinkage strain of about $15 \%$ and $22 \%$, respectively, indicating a very high swelling and shrinkage potential of this soil. Volume-change test specimens were treated with three geopolymer dosages and cured in air-tight chambers at $100 \%$ relative humidity with zero moisture loss. Geopolymer treatment was found to be highly effective for swell and shrinkage tests (as shown in Figure 6). Swelling potential of control $\mathrm{CH}$ was reduced by about $80 \%$ to $95 \%$ within $2 \mathrm{~h}$ of geopolymer application. Similarly, shrinkage potential was reduced by about $50 \%$ to $90 \%$ for all geopolymer dosages within a curing period of 3 days. Immediate swell and shrinkage reduction was observed for all geopolymer dosages within a few hours of geopolymer application. 


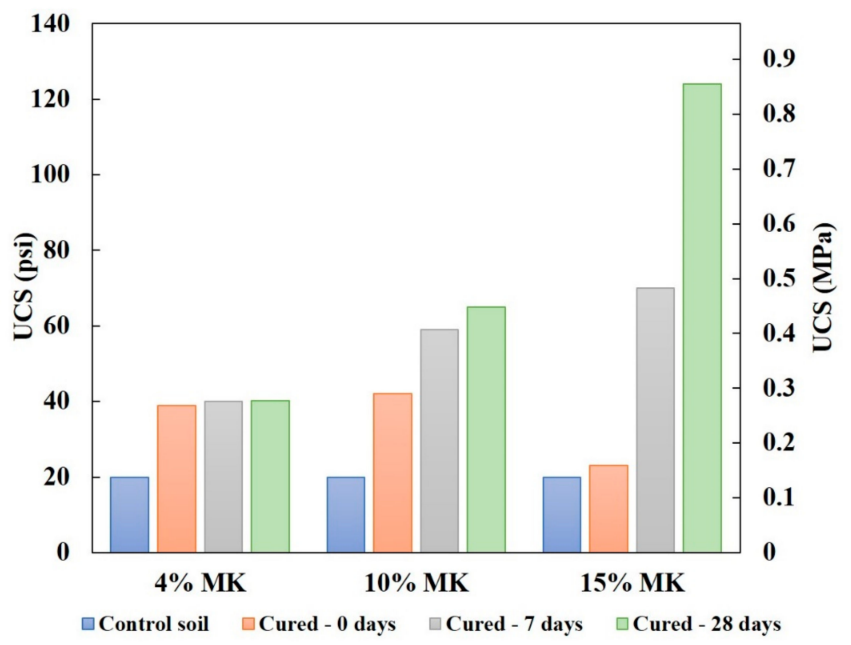

Figure 5. UCS test of control and geopolymer-treated high-plasticity clay $(\mathrm{CH})$. MK—-metakaolin.

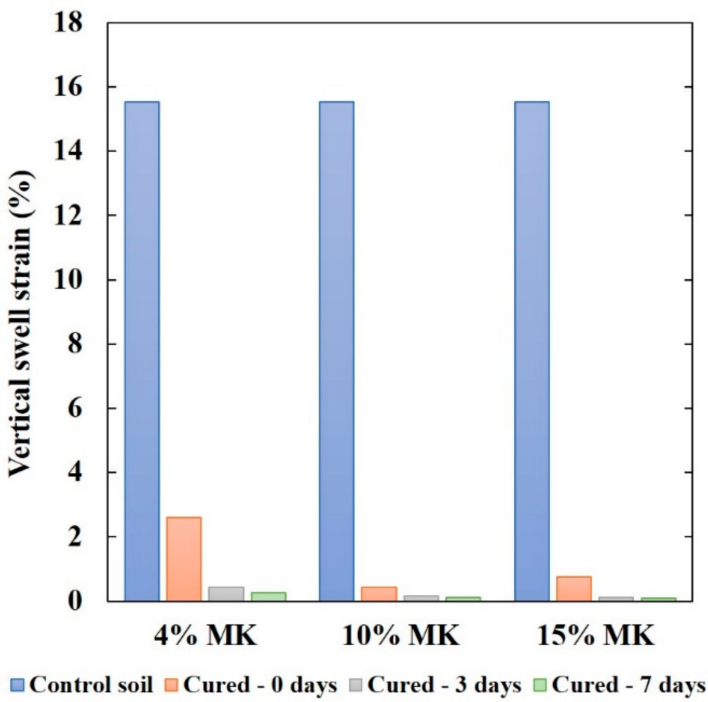

(a)

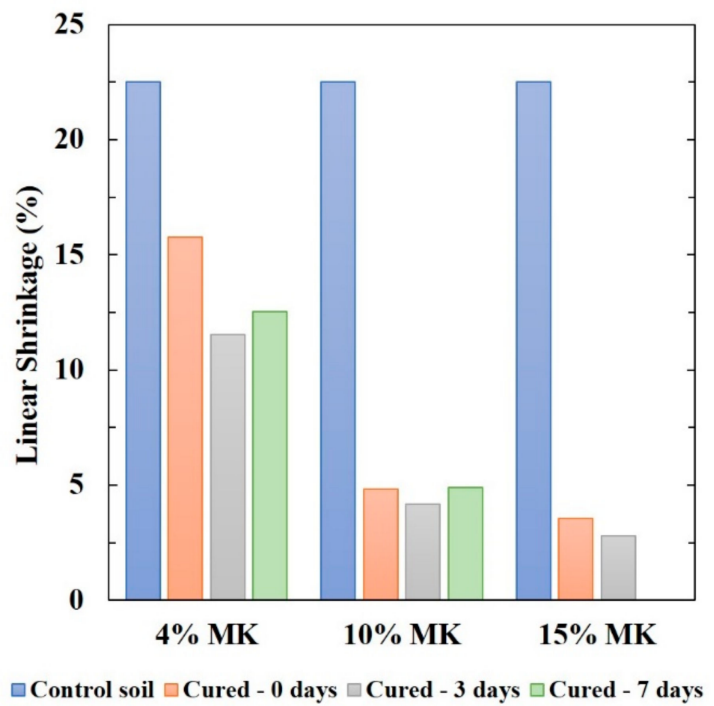

(b)

Figure 6. Volume-change tests of control and geopolymer-treated $\mathrm{CH}$ : (a) vertical swell strain plot; (b) linear shrinkage plot.

Based on previous tests, a 10\% MK dosage of geopolymer was found to be suitable for improvement of the high plasticity Lewisville clay $(\mathrm{CH})$ by increasing UCS and reducing swell and shrinkage strains [33,41]. It should be noted that swell and shrinkage strains reached to near $0 \%$ (swell strains) and around 5\% (shrinkage strains), respectively. Hence geopolymer with $10 \% \mathrm{MK}$ is recommended.

\section{Sustainability Benefits Assessment Framework}

The assessment of sustainability benefits of the metakaolin-based geopolymer in this study was performed by the estimation of the sustainability index $\left(\mathrm{I}_{\text {Sus }}\right)$ as per the framework recently introduced at University of Texas at Arlington [18,42]. The $\mathrm{I}_{\text {Sus }}$ of a material is proposed to be a function of its resource consumption, environmental impact, and socio-economic impact, and is estimated as shown in Equation (3):

$$
\mathrm{I}_{\text {Sus }}=\left(\mathrm{W}_{1} \times \mathrm{I}_{\text {Rec }}\right)+\left(\mathrm{W}_{2} \times \mathrm{I}_{\mathrm{Env}}\right)+\left(\mathrm{W}_{3} \times \mathrm{I}_{\text {SoEc }}\right)
$$

where, $\mathrm{I}_{\mathrm{Rec}}$ is the resource consumption index, $\mathrm{I}_{\mathrm{Env}}$ is the environmental impact index, $\mathrm{I}_{\mathrm{SoEc}}$ is the socio-economic impact index, and $\mathrm{W}_{1}, \mathrm{~W}_{2}$, and $\mathrm{W}_{3}$ are the weighted values of each associated index. 
The weighted values assigned for each index provide an insight into their relevance for a specific project and can be varied based on the executor's judgement. The I Sus $_{\text {can }}$ be estimated for different materials for a comparison of the values, with the material with the lowest $\mathrm{I}_{\text {Sus }}$ being the most sustainable. Life cycle assessment (LCA) is an essential process of obtaining the resource consumption and environmental impact aspects of the sustainability index. The following paragraphs describe the impact factors used in this study to determine the $\mathrm{I}_{\text {Sus. }}$.

Resource consumption was determined using energy accounting methods during life cycle inventory (LCI) analysis, which is a subset of LCA. The $\mathrm{I}_{\text {Rec }}$ was estimated using the embodied energy of materials using a "cradle to gate" approach which accounts for the energy expended during the process of production and transportation of materials. The embodied energy of materials used in the study were obtained from the literature [43] and is reported in megajoules (MJ).

Environmental impact assessment is a function of three major components-global warming potential, acidification potential, and eutrophication potential. The global warming potential $\left(\mathrm{GW}_{\mathrm{P}}\right)$ is an estimate of the impact of raw materials and manufacturing processes on the production of greenhouse gases, which consequentially raises the average global temperature. In this study, the $\mathrm{GW}_{\mathrm{P}}$ was represented by the amount of carbon dioxide produced contributing to global warming and is reported in gram equivalent of $\mathrm{CO}_{2}\left(\mathrm{gCO}_{2}\right.$ eq.). The acidification potential $\left(\mathrm{A}_{\mathrm{P}}\right)$ is the ability of a material to raise the acidity of soils or nearby water bodies by decreasing its $\mathrm{pH}$ and is measured in gram equivalent of $\mathrm{SO}_{2}$ ( $\left(\mathrm{gSO}_{2}\right.$ eq.). Increased $\mathrm{AP}_{\mathrm{P}}$ usually deposits itself in the form of acid rain, which is known to have harmful effects on living beings as well as infrastructure. The eutrophication potential $\left(\mathrm{E}_{\mathrm{P}}\right)$ is an indicator of biodiversity and ecological health and is measured in gram equivalent of $\mathrm{PO}_{4}{ }^{3-}$ ( $\mathrm{gPO}_{4}{ }^{3-}$ eq.). An increase in $\mathrm{E}_{\mathrm{P}}$ or over-nutrification is usually evident in aquatic systems by algal blooms that cause oxygen deficiency, leading to the death of other aerobic organisms, thereby disrupting the biodiversity of adjoining ecosystems.

A cost-benefit analysis is used to evaluate the socio-economic impact index $\left(\mathrm{I}_{\mathrm{SoEc}}\right)$ of different materials that can be used for a project. A life cycle costing (LCC) is used to quantify costs associated with each alternative usually including purchase, construction, operation, maintenance, rehabilitation, and other residual costs [18]. Weighted values are applied to the different categories used to calculate each of the indices, based on their relevance for the project A flowchart of the sustainability benefits assessment framework is shown in Figure 7. This was a pilot study of the sustainability benefits of geopolymers as soil stabilizers and therefore focused on the initial cost of materials.

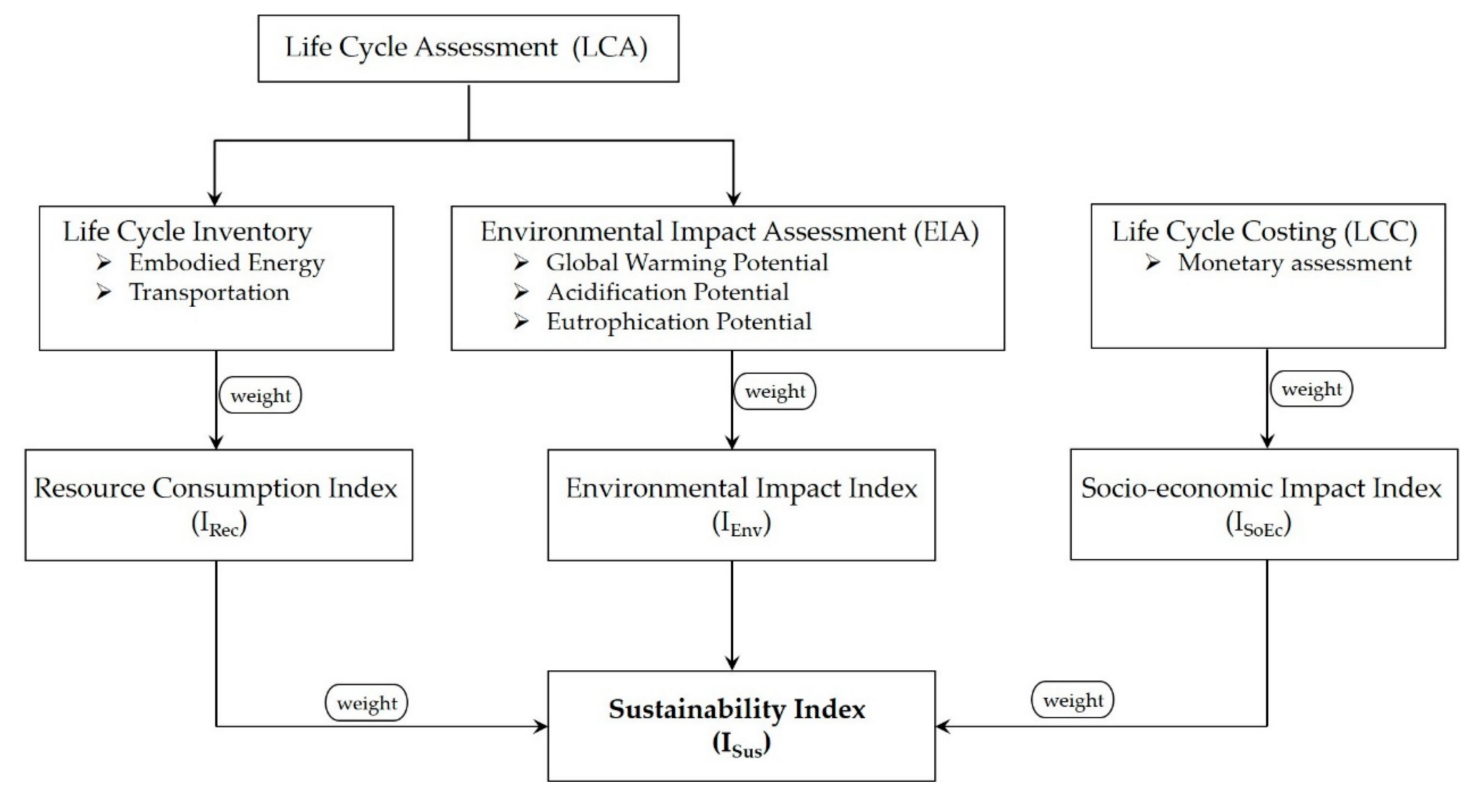

Figure 7. Sustainability assessment framework (adapted from [18]). 


\section{Comparative Sustainability Benefits}

Sustainability benefits were assessed for a laboratory-scale scenario comparing geopolymer and conventional lime treatment of the high-plasticity Lewisville clay $(\mathrm{CH})$. The assessment was performed for dosages of $10 \%$ MK for geopolymer treatment and $8 \%$ lime for lime treatment of the soil. The appropriate dosage of lime required to stabilize $\mathrm{CH}$ was determined based on the Eades and Grim pH test as per TEX 121-E, as well as the soluble sulfate content. In this study, ISus was evaluated for the primary components of both treatment methods for the same quantity of dry soil $(100 \mathrm{~kg})$. As such, this assessment analyzes the sustainability characteristics of metakaolin alone for the geopolymer treatment of soils, as other ingredients (silica fume, $\mathrm{KOH}$ ) were utilized in lower quantities. Conventional soil treatment of the high plasticity Lewisville clay was performed using commercially available lime. The summary of the treatment methods assessed for sustainability are provided in Table 2:

Table 2. Treatment methods assessed for sustainability.

\begin{tabular}{ccc}
\hline Treatment ID & A & B \\
\hline Treatment type & Geopolymer & Lime \\
Primary component (PC) & Metakaolin & Lime \\
Soil type & $\mathrm{CH}$ & $\mathrm{CH}$ \\
Dry soil $(\mathrm{kg})$ & 100 & 100 \\
Dosage & $10 \%$ Metakaolin & $8 \%$ Lime \\
PC quantity $(\mathrm{kg})$ & 10 & 8 \\
\hline
\end{tabular}

As explained earlier, the $\mathrm{I}_{\text {Sus }}$ was determined using indices for resource consumption, environmental impact, and socio-economic impact for metakaolin and lime. The embodied energy values for production of metakaolin, as well as its potential for global warming, acidification, and eutrophication were obtained from published literature [43]. The values for embodied energy used during the production of lime, and its acidification and eutrophication potential were obtained from previous studies [44]. The global warming potential of lime was obtained from the Inventory of Carbon and Energy (ICE) database [45]. Additionally, the embodied energy from transportation of materials from source to site was determined from the GREET (Greenhouse gases, Regulated Emissions, and Energy use in Transportation) model [46] developed by Argonne National Laboratory.

The resource consumption of both treatments based on the embodied energy consumed during their production and transportation are summarized in Table 3. The $\mathrm{I}_{\mathrm{Rec}}$ for the treatment methods were estimated using Equation (4) [18]:

$$
\mathrm{I}_{\mathrm{Rec}}=\mathrm{w}_{1 \mathrm{a}} \times \mathrm{E}_{\mathrm{E}(\text { material 1) }}+\mathrm{w}_{1 \mathrm{~b}} \times \mathrm{E}_{\mathrm{E}(\text { material 2) }}+\mathrm{w}_{1 \mathrm{c}} \times \mathrm{E}_{\mathrm{E}(\text { transportation })}
$$

where, $\mathrm{w}_{1 \mathrm{a}}, \mathrm{w}_{1 \mathrm{~b}}, \mathrm{w}_{1 \mathrm{c}}$ are weighted values of each parameter and $\mathrm{E}_{\mathrm{E}}$ is the embodied energy. The embodied energy consumed due to transportation of both materials was estimated to be $1.5 \mathrm{MJ} /$ metric ton-km [46], assuming a source to site distance of $80 \mathrm{~km}$ (50 miles) covered by a truck. The significantly higher consumption of resources per kg of lime than geopolymer is highlighted by placing higher weighted values on the embodied energy of lime. The resource consumption of Treatment A is observed to be lower than Treatment B with a lower $\mathrm{I}_{\text {Rec }}$ value of 46.67 .

The comparison of environmental impact indices of both treatments is presented in Table 4, where $\mathrm{I}_{\text {Env }}$ was calculated as per Equation (5) [18]:

$$
\mathrm{I}_{\mathrm{Env}}=\mathrm{w}_{2 \mathrm{a}} \times \mathrm{GW}_{\mathrm{P}}+\mathrm{w}_{2 b} \times \mathrm{A}_{\mathrm{P}}+\mathrm{w}_{2 \mathrm{c}} \times \mathrm{E}_{\mathrm{p}}
$$

where, $\mathrm{w}_{2 \mathrm{a}}, \mathrm{w}_{2 \mathrm{~b}}, \mathrm{w}_{2 \mathrm{c}}$ are weighted values of each parameter. The ever-increasing and unimpeded carbon dioxide emissions pose a more imminent concern on a global scale; therefore, higher weightage 
values were assigned for the $\mathrm{GW}_{P}$ of both treatments than its $A_{P}$ and $E_{P}$. Table 4 shows Treatment $A$ to have a significantly lower $\mathrm{I}_{\mathrm{Env}}$ value of 38.73 than Treatment $\mathrm{B}$.

Table 3. Calculation of resource consumption index $\left(\mathrm{I}_{\mathrm{Rec}}\right)$.

\begin{tabular}{cccccccc}
\hline & $\begin{array}{c}\text { Embodied Energy } \\
\text { Consumed (MJ) }\end{array}$ & $\begin{array}{c}\text { Per cent Consumption } \\
\text { of Embodied Energy (\%) }\end{array}$ & Weights & \multicolumn{2}{c}{ Weighted Resource Use } \\
\hline Treatment ID & $\mathrm{A}^{1}$ & $\mathrm{~B}^{2}$ & $\mathrm{~A}^{1}$ & $\mathrm{~B}^{2}$ & $\mathrm{~A}^{1}$ & $\mathrm{~B}^{2}$ \\
Geopolymer & 25 & 0 & 100.00 & 0.00 & 0.30 & 30.00 & 0.00 \\
Lime & 0 & 63 & 0.00 & 100.00 & 0.40 & 0.00 & 40.00 \\
Transportation & 1.2 & 0.96 & 55.56 & 44.44 & 0.30 & 16.67 & 13.33 \\
\hline \multicolumn{3}{c}{ Resource Consumption Index $\left(\mathrm{I}_{\text {Rec }}\right)$} & & 46.67 & 53.33 \\
\hline \multicolumn{7}{c}{${ }^{1}$ Geopolymer treatment, ${ }^{2}$ lime treatment. }
\end{tabular}

Table 4. Calculation of environmental impact index $\left(\mathrm{I}_{\mathrm{Env}}\right)$.

\begin{tabular}{|c|c|c|c|c|c|c|c|}
\hline \multirow[b]{2}{*}{ Treatment ID } & \multicolumn{2}{|c|}{$\begin{array}{l}\text { Emission } \\
\text { Contribution }\end{array}$} & \multicolumn{2}{|c|}{$\begin{array}{l}\text { Per cent Contribution } \\
\text { of Emission (\%) }\end{array}$} & \multirow[t]{2}{*}{ Weights } & \multicolumn{2}{|c|}{$\begin{array}{c}\text { Weighted } \\
\text { Environmental Impact }\end{array}$} \\
\hline & $\mathrm{A}^{1}$ & $\mathrm{~B}^{2}$ & $\mathrm{~A}^{1}$ & $\mathrm{~B}^{2}$ & & $\mathrm{~A}^{1}$ & $\mathrm{~B}^{2}$ \\
\hline $\begin{array}{c}\text { Global Warming } \\
\text { Potential ( } \mathrm{gCO}_{2} \text { eq.) }\end{array}$ & 3300 & 6240 & 34.59 & 65.41 & 0.60 & 20.75 & 39.25 \\
\hline $\begin{array}{c}\text { Acidification } \\
\text { Potential (gSO } \mathrm{gSO}_{2} \text { eq.) }\end{array}$ & 3.24 & 4.95 & 39.55 & 60.45 & 0.20 & 7.91 & 12.09 \\
\hline $\begin{array}{c}\text { Eutrophication } \\
\text { Potential ( } \mathrm{gPO}_{4}{ }^{3-} \text { eq.) }\end{array}$ & 0.65 & 0.64 & 50.30 & 49.70 & 0.20 & 10.06 & 9.94 \\
\hline \multicolumn{6}{|c|}{ Environmental Impact Index (I $\left.\mathrm{I}_{\text {Env }}\right)$} & 38.73 & 61.27 \\
\hline
\end{tabular}

The socio-economic impact of the treatments was estimated based on the average unit price of lime obtained from manufacturers and are presented in Table 5 . The unit price of the conventional Treatment B was found to be 0.12 USD per $\mathrm{kg}$ [47], and the unit price of the novel Treatment A was assumed to be $50 \%$ more than the unit price of Treatment B. Note that the actual unit price of Treatment A is significantly higher and it can be attributed to low demand. The higher cost contribution of Treatment $\mathrm{A}$ is attributed to the higher unit price of the novel Treatment A compared to the low unit price of the mainstream Treatment $B$, in addition to the higher quantity of novel material required for soil treatment. The $\mathrm{I}_{\mathrm{SoEc}}$ was calculated using Equation (6) as [18]:

$$
\mathrm{I}_{\mathrm{SoEc}}=\mathrm{w}_{3} \times \mathrm{C}
$$

where $\mathrm{w}_{3}=1.0$, and $\mathrm{C}$ is the total cost of treatment. Treatment $\mathrm{B}$ was found to have a lower socio-economic impact with a lower $\mathrm{I}_{\mathrm{SoEc}}$ value of 34.78 .

Table 5. Calculation of environmental impact index $\left(\mathrm{I}_{\mathrm{SoEc}}\right)$.

\begin{tabular}{|c|c|c|c|c|c|c|c|}
\hline \multirow[b]{2}{*}{ Treatment ID } & \multicolumn{2}{|c|}{$\begin{array}{c}\text { Cost } \\
\text { Contribution }\end{array}$} & \multicolumn{2}{|c|}{$\begin{array}{c}\text { Per cent Contribution } \\
\text { of Cost }(\%)\end{array}$} & \multirow[t]{2}{*}{ Weights } & \multicolumn{2}{|c|}{$\begin{array}{c}\text { Weighted } \\
\text { Socio-Economic Impact }\end{array}$} \\
\hline & $\mathrm{A}^{1}$ & $\mathrm{~B}^{2}$ & $\mathrm{~A}^{1}$ & $\mathrm{~B}^{2}$ & & $\mathrm{~A}^{1}$ & $\mathrm{~B}^{2}$ \\
\hline Cost of treatment (USD) & 1.80 & 0.96 & 65.22 & 34.78 & 1.0 & 65.22 & 34.78 \\
\hline \multicolumn{6}{|c|}{ Socio-Economic Impact Index (ISoEc) } & 65.22 & 34.78 \\
\hline
\end{tabular}

Finally, the ISus of both treatments was calculated by adding the weighted values of the three indices as shown in Equation (1) and is summarized in Table 6. For the calculation of $\mathrm{I}_{\text {Sus }}$, both the $\mathrm{I}_{\text {Rec }}$ and $\mathrm{I}_{\text {Env }}$ were assigned a weight of $40 \%$ while, the $\mathrm{I}_{\mathrm{SoEc}}$ was assigned a lower weight of $20 \%$, since current cost estimates need to be further adjusted based on future supply and demand, in addition to cost being a secondary aspect of this study. According to the sustainability benefits assessment, 
Treatment A (geopolymers) is deemed a more sustainable alternative with a lower $\mathrm{I}_{\text {Sus }}$ value than using Treatment B (lime) for soil improvement. It is important to note that the weighted values applied to each of the indices calculated are left to the discretion of the user. The weighted values will vary significantly for each project and will need to be verified by the user to be reliable and meaningful for the respective application and expected end-goal. The sustainability assessment framework can be used to effectively compare different alternatives for a project, to determine the most sustainable alternative.

Table 6. Calculation of sustainability index ( $\left.\mathrm{I}_{\text {Sus }}\right)$.

\begin{tabular}{|c|c|c|c|c|c|}
\hline \multirow[b]{2}{*}{ Treatment ID } & \multicolumn{2}{|c|}{ Index Value } & \multirow[t]{2}{*}{ Weights } & \multicolumn{2}{|c|}{ Weighted Index } \\
\hline & $\mathrm{A}^{1}$ & $\mathrm{~B}^{2}$ & & $\mathrm{~A}^{1}$ & $\mathrm{~B}^{2}$ \\
\hline Resource Consumption $\left(\mathrm{I}_{\operatorname{Rec}}\right)$ & 46.67 & 53.33 & 0.40 & 18.67 & 21.33 \\
\hline Environmental Impact ( $\left.\mathrm{I}_{\text {Env }}\right)$ & 38.73 & 61.27 & 0.40 & 15.49 & 24.51 \\
\hline Socio-Economic Impact ( $\left.\mathrm{I}_{\mathrm{SoEc}}\right)$ & 65.22 & 34.78 & 0.20 & 13.04 & 6.96 \\
\hline \multicolumn{4}{|c|}{ Sustainability Index $\left(\mathrm{I}_{\text {Sus }}\right)$} & 47.20 & 52.80 \\
\hline
\end{tabular}

Figure 8 shows a graphical representation of the different aspects of the sustainability benefits assessment. It is to be noted that the radar chart does not reflect the unequal individual weights applied to each of the parameters to evaluate the indices [18]. The structural integrity characteristics representative of resiliency, namely probability of fatigue cracking and rutting failure, are also included in this radar chart for a better comparison of both treatments. The hypothetical pavement section and design system used for evaluating the resiliency characteristics have been described in detail in [33]. From Figure 8, the area under geopolymer treatment was estimated to be about 0.64 square units, while it was larger for lime treatment with an estimate of 0.86 square units. Therefore, Treatment $\mathrm{A}$ (geopolymer) is confirmed to be a more sustainable alternative than Treatment B (lime) based on the assumptions of the sustainability benefits assessment elaborated in this study.

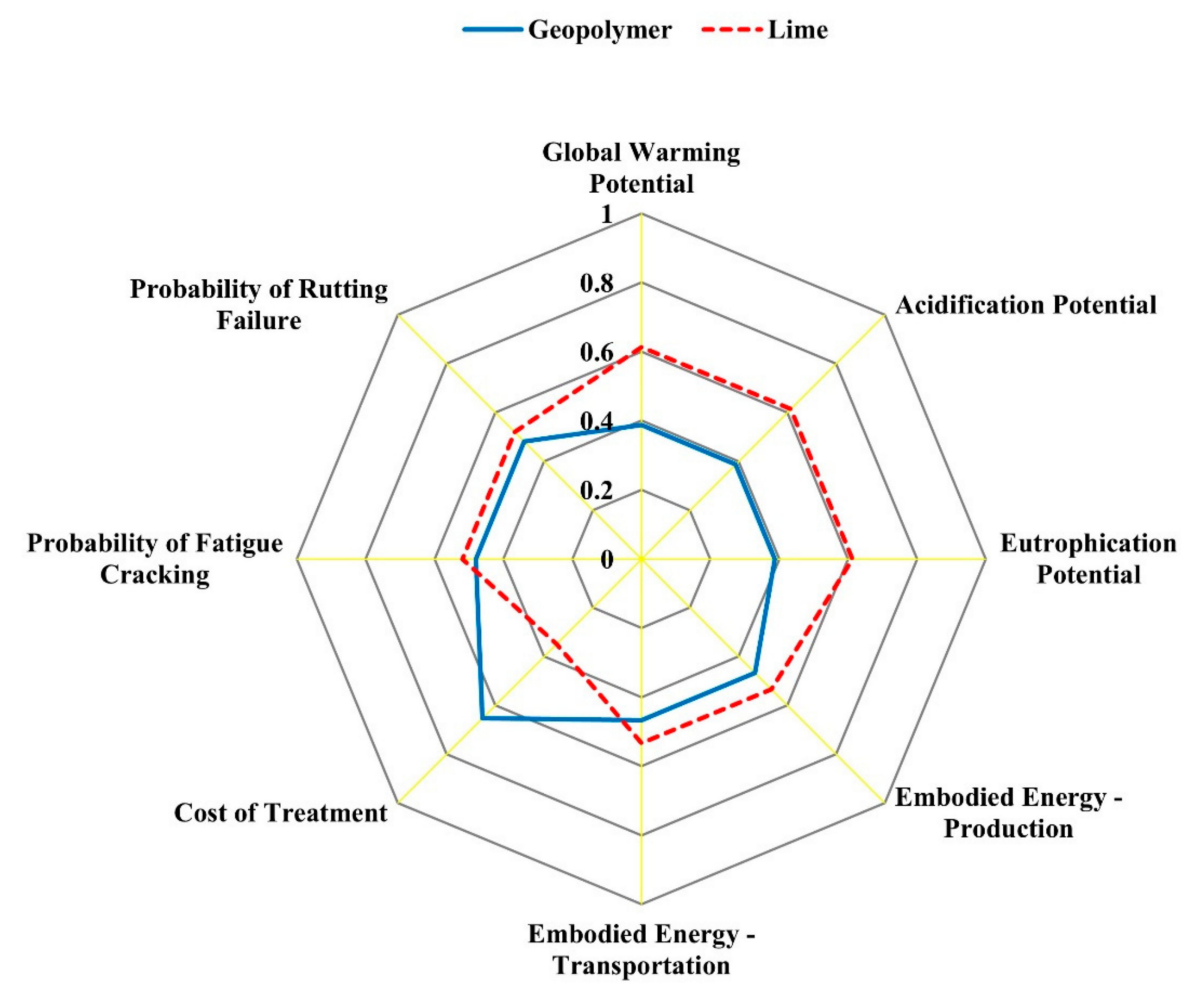

Figure 8. Graphical representation of sustainability benefits assessment [33]. 


\section{Conclusions}

Conventional chemical additives such as lime and cement have been used to effectively stabilize expansive soils. The production of lime and cement are major contributors to global greenhouse gas emissions and are therefore not sustainable. Recently, geopolymers have been investigated as alternatives for soil stabilization, due to comparable strength and volume-change properties. This study presents the sustainability benefits assessment of a metakaolin-based geopolymer-treatment for a high plasticity expansive soil, and its comparison with lime-treatment. The sustainability benefits framework used a weighted multi-criteria assessment to estimate a sustainability index ( $\mathrm{I}_{\text {Sus }}$ ) for each treatment method. The global warming potential and embodied energy of production of a kilogram of lime were found to be significantly higher than metakaolin, the primary component of the geopolymer. Based on the weightage applied as well as assumptions regarding cost and transportation, the metakaolin-based geopolymer with a lower ISus was found to be a more sustainable alternative to the conventional lime treatment for soil stabilization.

Author Contributions: The authors confirm contribution to the paper as follows: study conception and design: A.J.P., R.S., and M.R.; data collection: R.S.; analysis and interpretation of results: R.S.; draft manuscript preparation: R.S. All authors have read and agreed to the published version of the manuscript.

Funding: This research was funded by the USDOT's Transportation Consortium for South-Central States (Tran-SET), under research grants 17GTTAM02 and 18CTAMU04.

Acknowledgments: The authors gratefully acknowledge the USDOT's Transportation Consortium for SouthCentral States (Tran-SET), who funded this study. The first author of this article was the recipient of the USDOT's Dwight D. Eisenhower Transportation Fellowship for the years 2017-2019 and is thankful for the financial support provided. Any findings, conclusions, or recommendations expressed in this material are those of the authors and do not necessarily reflect the views of the funding agency.

Conflicts of Interest: The authors declare no conflict of interest.

\section{References}

1. Low, P.F. Structural component of the swelling pressure of clay. Langmuir 1987, 3, 18-25. [CrossRef]

2. Nelson, J.D.; Chao, K.C.; Overton, D.D.; Nelson, E.J. Foundation Engineering for Expansive Soils; John Wiley \& Sons: Hoboken, NJ, USA, 2015.

3. Nelson, J.D.; Miller, D.J. Expansive Soils: Problems and Practice in Foundation and Pavement Engineering; John Wiley \& Sons: Hoboken, NJ, USA, 1992.

4. Olive, W.W.; Chleborad, A.F.; Frahme, C.W.; Schlocker, J.; Schneider, R.R.; Schuster, R.L. Swelling Clays Map of the Conterminous United States; USGS: Reston, VA, USA, 1989.

5. Steinberg, M.L. Geomembranes and the Control of Expansive Soils in Construction; McGraw-Hill: New York, NY, USA, 1998; ISBN 0070611785.

6. Saride, S.; Puppala, A.J.; Williammee, R. Assessing recycled/secondary materials as pavement bases. Proceedings of the ICE. Ground Improv. 2010, 163, 3-12. [CrossRef]

7. Puppala, A.; Hoyos, L.; Viyanant, C.; Musenda, C. Fiber and fly ash stabilization methods to treat soft expansive soils. Soft Ground Technol. 2001, 11, 136-145.

8. Jones, D.E.; Holtz, W.G. Expansive soils-The hidden disaster. Civ. Eng. 1973, 43, 49-51.

9. Puppala, A.J.; Cerato, A. Heave distress problems in chemically-treated sulfate-laden materials. Geo-Strata 2009, 10, 28.

10. Samuel, R.; Huang, O.; Banerjee, A.; Puppala, A.; Das, J.; Radovic, M. Case Study: Use of Geopolymers to Evaluate the Swell-Shrink Behavior of Native Clay in North Texas. Eighth Int. Conf. Case Hist. Geotech. Eng. 2019, 167-178. [CrossRef]

11. Little, D.N. Handbook for Stabilization of Pavement Subgrades and Base Courses with Lime; Lime Association of Texas: Austin, TX, USA, 1995; ISBN 0840396325.

12. Petry, T.M.; Little, D.N. Review of Stabilization of Clays and Expansive Soils in Pavements and Lightly Loaded Structures-History, Practice, and Future. J. Mater. Civ. Eng. 2002, 14, 447-460. [CrossRef] 
13. Puppala, A.J.; Congress, S.S.C.; Banerjee, A. Research Advancements in Expansive Soil Characterization, Stabilization and Geoinfrastructure Monitoring. In Frontiers in Geotechnical Engineering; Springer: Singapore, 2019; pp. 15-29. [CrossRef]

14. Katz, L.; Rauch, A.; Liljestrand, H.; Harmon, J.; Shaw, K.; Albers, H. Mechanisms of soil stabilization with liquid ionic stabilizer. Transp. Res. Rec. 2001, 1757, 50-57. [CrossRef]

15. Puppala, A.J.; Intharasombat, N.; Vempati, R.K. Experimental Studies on Ettringite-Induced Heaving in Soils. J. Geotech. Geoenviron. Eng. 2005, 131, 325-337. [CrossRef]

16. U.S. Environmental Protection Agency. Greenhouse Gas Reporting Program (GHGRP)-GHGRP Minerals. 2020. Available online: https://www.epa.gov/ghgreporting/ghgrp-minerals (accessed on 15 August 2019).

17. Brundtland, G.H. Report of the World Commission on Environment and Development: “Our Common Future". United Nations Gen. Assem. 1987. Available online: https://sustainabledevelopment.un.org/content/ documents/5987our-common-future.pdf (accessed on 15 August 2019).

18. Das, J.T. Assessment of Sustainability and Resilience in Transportation Infrastructure Geotechnics; University of Texas at Arlington: Arlington, TX, USA, 2018.

19. Pantelidou, H.; Nicholson, D.; Gaba, A. Sustainable Geotechnics. Man. Geotech. Eng. 2012. [CrossRef]

20. Graedel, T. Industrial ecology: Definition and implementation. Ind. Ecol. Glob. Chang. 1994. [CrossRef]

21. Kibert, C.J. Sustainable Construction: Green Building Design and Delivery; John Wiley \& Sons: Hoboken, NJ, USA, 2016.

22. Davidovits, J. Geopolymer Chemistry and Applications; Institut Géopolymère, Geopolymer Institute: Saint-Quentin, France, 2008.

23. Provis, J.L.; van Deventer, J.S.J. Geopolymers: Structures, Processing, Properties and Industrial Applications; Elsevier: Amsterdam, The Netherlands, 2009.

24. Duxson, P.; Fernández-Jiménez, A.; Provis, J.L.; Lukey, G.C.; Palomo, A.; van Deventer, J.S.J. Geopolymer technology: The current state of the art. J. Mater. Sci. 2007, 42, 2917-2933. [CrossRef]

25. Davidovits, J. Geopolymers-Inorganic polymeric new materials. J. Therm. Anal. 1991, 37, 1633-1656. [CrossRef]

26. Van Jaarsveld, J.G.S.; van Deventer, J.S.J.; Lukey, G.C. The effect of composition and temperature on the properties of fly ash-and kaolinite-based geopolymers. Chem. Eng. J. 2002, 89, 63-73. [CrossRef]

27. Cheng, T.W.; Chiu, J.P. Fire-resistant geopolymer produced by granulated blast furnace 5 slag. J. Miner. Eng. 2003, 16, 205-210. [CrossRef]

28. Gordon, M.; Bell, J.L.; Kriven, W.M. Comparison of naturally and synthetically-derived potassium-based geopolymers. Ceram. Trans. Ser. 2005, 165, 95-106.

29. Lizcano, M.; Gonzalez, A.; Basu, S.; Lozano, K.; Radovic, M. Effects of Water Content and Chemical Composition on Structural Properties of Alkaline Activated Metakaolin-Based Geopolymers. J. Am. Ceram. Soc. 2012, 95, 2169-2177. [CrossRef]

30. Gartner, E. Industrially interesting approaches to “low- $\mathrm{CO}_{2}$ ” cements. Cem. Concr Res. 2004, 34, 1489-1498. [CrossRef]

31. Bell, J.L.; Driemeyer, P.E.; Kriven, W.M. Formation of ceramics from metakaolin-based geopolymers. Part II: K-based geopolymer. J. Am. Ceram. Soc. 2009, 92, 607-615. [CrossRef]

32. Medri, V.; Fabbri, S.; Dedecek, J.; Sobalik, Z.; Tvaruzkova, Z.; Vaccari, A. Role of the morphology and the dehydroxylation of metakaolins on geopolymerization. Appl. Clay Sci. 2010, 50, 538-545. [CrossRef]

33. Samuel, R.A. Synthesis of Metakaolin-based Geopolymer and its Performance as Sole Stabilizer of Expansive Soils; University of Texas at Arlington: Arlington, TX, USA, 2019.

34. Duxson, P.; Provis, J.L.; Lukey, G.C.; Mallicoat, S.W.; Kriven, W.M.; van Deventer, J.S.J. Understanding the relationship between geopolymer composition, microstructure and mechanical properties. Colloids Surf. A Physicochem. Eng. Asp. 2005, 269, 47-58. [CrossRef]

35. Steins, P.; Poulesquen, A.; Diat, O.; Frizon, F. Structural evolution during geopolymerization from an early age to consolidated material. Langmuir 2012, 28, 8502-8510. [CrossRef] [PubMed]

36. Zhang, M.; Zhao, M.; Zhang, G.; Nowak, P.; Coen, A.; Tao, M. Calcium-free geopolymer as a stabilizer for sulfate-rich soils. Appl. Clay Sci. 2015, 108, 199-207. [CrossRef]

37. Khadka, S.D.; Jayawickrama, P.W.; Senadheera, S. Strength and shrink/swell behavior of highly plastic clay treated with geopolymer. Transp. Res. Rec. 2018, 2672, 174-184. [CrossRef]

38. Caldrone, M.A.; Gruber, K.A.; Burg, R.G. High reactivity Metakaolin: A new generation mineral admixture for high performance concrete. Concr. Int. 1994, 16, 11. 
39. Gruber, K.A.; Ramlochan, T.; Boddy, A.; Hooton, R.D.; Thomas, M.D.A. Increasing concrete durability with high-reactivity metakaolin. Cem. Concr. Compos. 2001, 23, 479-484. [CrossRef]

40. McManis, K.L.; Arman, A. Class C fly ash as a full or partial replacement for portland cement or lime. Transp. Res. Rec. 1989, 1219, 68-81.

41. Samuel, R.; Puppala, A.J.; Banerjee, A.; Huang, O.; Radovic, M.; Chakraborty, S. Improvement of Strength and Volume-Change Properties of Expansive Clays with Geopolymer Treatment. Transp. Res. Rec.. (under review).

42. Puppala, A.J.; Das, J.T.; Bheemasetti, T.V.; Congress, S.S.C. Sustainability and Resilience in Transportation Infrastructure geotechnics: Integrating Advanced Technologies for better Asset Management. Geo-Strata 2018, 22, 42-48.

43. Heath, A.; Paine, K.; McManus, M. Minimising the global warming potential of clay based geopolymers. J. Clean. Prod. 2014, 78, 75-83. [CrossRef]

44. Da Rocha, C.G.; Passuello, A.; Consoli, N.C.; Quiñónez Samaniego, R.A.; Kanazawa, N.M. Life cycle assessment for soil stabilization dosages: A study for the Paraguayan Chaco. J. Clean. Prod. 2016, 139, 309-318. [CrossRef]

45. Hammond, G.; Jones, C.; Lowrie, F.; Tse, P. Embodied Carbon: The Inventory of Carbon and Energy (ICE); University of Bath and BSRIA: Bracknell, UK, 2011.

46. Wang, M.Q. Technical Report: GREET 1.5 -Transportation Fuel-Cycle Model: Methodology, Development, Use, and Results; Argonne National Lab.: Argonne, IL, USA, 1999.

47. Corathers, L.A.; Apodaca, L.E. Lime [Advance Release]. In Metals and Minerals: U.S. Geological Survey Minerals Yearbook 2016; U.S. Geological Survey (USGS): Reston, VA, USA, 2016; pp. 43.1-43.13. [CrossRef]

Publisher's Note: MDPI stays neutral with regard to jurisdictional claims in published maps and institutional affiliations. 